\title{
Blackcurrant gall mite - Cecidophyopsis ribis (Westw.), harmfulness and possibility to control with fenpyroximate (Ortus 05 SC)
}

\section{Wielkopąkowiec porzeczkowy - Cecidophyopsis ribis (Westw.), szkodliwość oraz możliwości zwalczania przy użyciu fenpiroksymatu (Ortus 05 SC)}

\author{
Barbara H. Łabanowska*, Wojciech Piotrowski, Małgorzata Gruchała
}

\begin{abstract}
Summary
The blackcurrant gall mite (big bud mite) - Cecidophyopsis ribis (Westw.) is the most dangerous pest of blackcurrant in many countries. C. ribis is a key pest in Poland and causes severe damage on some plantations, destroying even more than $50 \%$ of the buds. The big bud mite infests most of the commonly grown cultivars and only a few are resistant. Looking for new possibilities to control the pest is still necessary. The experiments were carried out at the Research Institute of Horticulture in 2008-2011. Fenpyroximate active substance in Ortus $05 \mathrm{SC}$ showed high effectiveness in reducing the number of the blackcurrant gall mites emerging from treated buds. Ortus $05 \mathrm{SC}(1.25 ; 1.5 \mathrm{l} / \mathrm{ha})$ and Ortus $05 \mathrm{SC}(1.5 \mathrm{l} / \mathrm{ha})+$ Slippa $(0.1 \mathrm{l} / \mathrm{ha})$ applied 3 times during migration of the big bud mite, reduced the number of damaged buds by $76-90 \%$ compared to the control bush. Also Ortus 05 SC ( $1.5 \mathrm{l} /$ ha), applied twice: at the beginning and during the full blossom of black currant significantly reduced the number of buds infested by the big bud mite. On the bushes where Ortus $05 \mathrm{SC}(1.5 \mathrm{l} / \mathrm{ha})+$ Slippa $(0.1 \mathrm{l} / \mathrm{ha})$ were used twice, slightly less damaged buds compared with the treatments without wetting were reported, but the differences were not statistically significant.
\end{abstract}

Key words: Cecidophyopsis ribis; blackcurrant; chemical control; fenpyroximate

\begin{abstract}
Streszczenie
Wielkopąkowiec porzeczkowy - Cecidophyopsis ribis jest bardzo ważnym szkodnikiem porzeczki czarnej w wielu krajach, również w Polsce, zasiedlającym większość uprawianych odmian, tylko nieliczne są odporne. Na niektórych plantacjach niszczy ponad 50\% pąków. Konieczne jest systematyczne poszukiwanie nowych środków do jego zwalczania. Badania prowadzono w latach 2008-2011 w Instytucie Ogrodnictwa w Skierniewicach. Fenpiroksymat (Ortus 05 SC) wykazał wysoką efektywność w redukcji szpecieli wychodzących z traktowanych pąków. Ortus 05 SC (1,25; 1,5 I/ha) i Ortus 05 SC (1,5 l/ha) + Slippa $(0,1 \mathrm{l} /$ ha), zastosowany 3-krotnie podczas migracji wielkopąkowca porzeczkowego, ograniczał liczbę uszkodzonych pąków o 76-90\% w porównaniu do krzewów kontrolnych. Również Ortus 05 SC (1,5 l/ha), aplikowany dwukrotnie - na początku i podczas pełni kwitnienia porzeczki czarnej, istotnie redukował liczbę pąków zasiedlonych. Na krzewach chronionych dwukrotnie preparatem Ortus 05 SC (1,5 l/ha) + Slippa $(0,1 \mathrm{l} / \mathrm{ha})$ notowano nieco mniej uszkodzonych pąków w porównaniu z zabiegami bez zwilżacza, ale różnice nie były istotne statystycznie.
\end{abstract}

Słowa kluczowe: Cecidophyopsis ribis; porzeczka czarna; zwalczanie; fenpiroksymat

Instytut Ogrodnictwa

Zakład Ochrony Roślin Sadowniczych

Pracownia Entomologii

Konstytucji 3 Maja 1/3, 96-100 Skierniewice

*corresponding author: Barbara.Labanowska@inhort.pl 


\section{Wstęp / Introduction}

Dynamiczny rozwój uprawy porzeczki czarnej w Polsce był możliwy po wprowadzeniu mechanicznego zbioru owoców (Salamon 1993). Jednym z najważniejszych szkodników porzeczki czarnej był i jest wielkopąkowiec porzeczkowy (Cecidophyopsis ribis) (Łabanowska 1996, 2011; Niemczyk i wsp. 2000; Alford 2007; Łabanowska i Gajek 2013). Dorosłe szpeciele oraz larwy żerują w pąkach, które powiększają się, ale nie rozwijają się z nich kwiaty. Pąki wiosną zasychają i powodują ogołacanie pędów. Szpeciel jest jedynym wektorem rewersji porzeczki czarnej Black currant reversion virus - BRV (Jones 1993; Pluta i wsp. 2000; Pluta i Żurawicz 2002), która wspólnie z wielkopąkowcem porzeczkowym istotnie redukuje plon, często o $50-60 \%$ prowadząc do likwidacji plantacji. Szpeciel rozprzestrzenia się z zasiedlonymi sadzonkami oraz podczas migracji, która rozpoczyna się przed kwitnieniem, ale przede wszystkim ma miejsce $\mathrm{w}$ czasie kwitnienia i tuż po nim, kiedy szpeciele wychodzą z pąków i przemieszczają się na liście (Łabanowska 2011). Na plantacji szpeciele rozprzestrzeniają się z wiatrem (Smolarz 1993), z kroplami wody oraz na ciele owadów i roztoczy wędrujących po roślinach. Wielkopąkowiec musi być zwalczany na prawie wszystkich plantacjach porzeczki czarnej (Łabanowska 2010). Po wycofaniu endosulfanu, amitrazu, a później także karbosulfanu, nie było środków do zwalczania tego szkodnika (Gajek i Olszak 2004; Łabanowska 2011). Rola fauny pożytecznej [drapieżne roztocze (Phytoseiidae) i parazytoid Tetrastichus eriophyes (Eulophidae)] w redukcji szpecieli jest marginalna (Gajek 2000). W Szkocji i w Polsce wyhodowano odmiany odporne lub mało podatne (Brennan i wsp. 1993; Pluta i wsp. 2000; Brennan i wsp. 2008, 2009; Łabanowska i Pluta 2010), ale nadal konieczne jest poszukiwanie nowych szans zwalczania szkodnika.

Celem badań była ocena możliwości zwalczania wielkopąkowca porzeczkowego podczas migracji, dostępnym na rynku fenpiroksymatem (Ortus 05 SC).

\section{Materiały i metody / Materials and methods}

Doświadczenia prowadzono $\mathrm{w}$ laboratorium oraz na prywatnych plantacjach porzeczki czarnej w województwie łódzkim w latach 2008-2011. W doświadczeniach laboratoryjnych (2008 r.) pąki uszkodzone przez szpeciela zanurzano $\mathrm{w}$ cieczy $\mathrm{z}$ preparatem, w polowo-laboratoryjnych zbierano pąki uszkodzone na plantacji po opryskiwaniu akarycydami, które w laboratorium wykładano na liście porzeczki umieszczone w szalkach Petriego na wilgotnej bibule filtracyjnej. Po 1, 3 i 5 dniach liczono żywe szpeciele, które wyemigrowały z pąków traktowanych środkami i z kontrolnych.

Doświadczenia polowe zakładano na kilkuletnich plantacjach porzeczki metodą bloków losowanych w 4 powtórzeniach. Jedno poletko/powtórzenie obejmowało powierzchnię $80 \mathrm{~m}^{2}$ (1-2 rzędy długości 20 lub 10 metrów). Zabiegi zwalczające prowadzono (Ortus 05 SC, Marshal 250 SC i Ortus 05 SC + Slippa) zgodnie z zaplanowanym programem podanym przy poszczególnych doświadczeniach.

\section{Doświadczenie I i II, Kamion, Mokra Lewa 2008/2009}

Doświadczenie I założono na plantacji porzeczki czarnej, odmiany Ben Lomond w Kamionie, natomiast II na odmianie Ojebyn w Mokrej Lewej. Wiosną 2008 roku, na każdej plantacji przed kwitnieniem, przed zabiegiem wydzielono poletka, wybrano i oznaczono na nich po 6 pędów ( 24 z kombinacji), na których część pąków była uszkodzona przez wielkopąkowca. Przeglądano dokładnie pędy licząc pąki zdrowe i z objawami uszkodzenia przez wielkopąkowca porzeczkowego. Następnie określono procent pąków uszkodzonych. Na oznaczonych pędach na plantacji w Kamionie uszkodzonych było 11,3-19,0\%, a w Mokrej Lewej 12,8-16,0\% pąków. Zabiegi zwalczające przeprowadzono podczas migracji szpecieli, terminy podano pod tabelami.

Efektywność zwalczania szkodnika oceniono 14 kwietnia 2009 roku, na początku wegetacji, kiedy łatwo było rozpoznać uszkodzone pąki. Ponownie, bezpośrednio na plantacji przeglądano oznaczone rok wcześniej pędy i sprawdzano pąki, licząc zdrowe oraz uszkodzone przez wielkopąkowca porzeczkowego. Następnie określono procent uszkodzonych pąków.

\section{Doświadczenie III, Mokra Lewa 2009/2010}

Doświadczenie III założono na 5-letniej plantacji odmiany Ojebyn. Przed zabiegiem, 24 kwietnia 2009 roku na każdym poletku doświadczalnym zaznaczono 7 pędów, na których były pojedyncze pąki uszkodzone (grupa I) oraz 7 pędów bez objawów zasiedlenia przez szkodnika (grupa II). W pierwszej grupie pędów określono liczbę pąków zdrowych i zasiedlonych. Pod koniec marca 2010 roku bezpośrednio na plantacji przeglądano wszystkie zaznaczone przed zabiegiem pędy, notując liczbę pąków zdrowych i zasiedlonych przez szpeciela. Obliczono procent uszkodzonych pąków w każdej grupie i skuteczność w procentach według wzoru Abbotta (1925). Wyniki z 2010 roku dla pierwszej grupy pędów, porównano z wykonanymi w 2009 roku. Obliczono redukcję lub wzrost zasiedlonych przez szpeciele pąków w procentach.

\section{Doświadczenie IV i V, Mokra Lewa 2010/2011}

Doświadczenie IV i V założono na 6-letnich plantacjach odmian Ojebyn i Tiben odpowiednio. Ocenę przed zabiegiem (kwiecień 2010 r.) oraz po zabiegach (koniec marca 2011 r.) wykonano w taki sposób, jak w doświadczeniu III.

We wszystkich doświadczeniach opryskiwania wykonywano opryskiwaczem plecakowo-motorowym „Stihl 420", zużywając w przeliczeniu 7501 cieczy na ha. Uzyskane wyniki opracowano statystycznie metodą analizy wariancji wykonanej na wartościach rzeczywistych (\% uszkodzonych pąków) przekształconych według transformacji Blissa. Różnice między średnimi oceniano przy użyciu testu Newmana-Keulsa przy poziomie istotności 5\%. Efektywność preparatów (w \%) obliczono według wzoru Abbotta: A-B/A × [100\%], gdzie A - liczba uszko- 
dzonych pąków w kontroli, B - liczba uszkodzonych pąków w kombinacji doświadczalnej.

\section{Wyniki i dyskusja / Results and discussion}

W testach laboratoryjnych z pąków zasiedlonych przez szpeciela i zanurzanych $w$ cieczy $z$ preparatem Ortus $05 \mathrm{SC}$ wychodziły tylko pojedyncze osobniki. Wysoka efektywność $(99,9-100 \%)$ notowano w kombinacji Ortus $05 \mathrm{SC}+$ zwilżacz Slippa, podobnie jak z preparatem standardowym Marshal 250 SC (karbosulfan). Ortus 05 SC (2,0 l/ha, w przeliczeniu) redukował wychodzące szpeciele o 98,6-100\%, zależnie od terminu obserwacji i testu. Ortus $05 \mathrm{SC}$ w niższych dawkach (w przeliczeniu 1,25 i 1,5 1/ha), redukował szpeciele na poziomie $86,5-100 \%$, w stosunku do kontroli. Nie zawsze stwierdzone były istotne różnice w zależności od zastosowanej dawki preparatu.

W badaniach polowo-laboratoryjnych (2008 r.) stwierdzono wyraźne ograniczenie liczby żywych szpecieli, które wyemigrowały $\mathrm{z}$ pąków traktowanych preparatem Ortus $05 \mathrm{SC}$ na liście w laboratorium. Na pąkach z plantacji w miejscowości Kamion, redukcja szkodnika była na poziomie 85,0-99,1\%, a z Mokrej Lewej - 98,7-99,9\% (szpeciele mogły być ograniczane także przez drapieżne roztocze z rodziny Phytoseiidae). Wyniki zwykle były podobne, niezależnie od zastosowanej dawki preparatu Ortus 05 SC (1,25 i 1,5 1/ha) i dodatku zwilżacza Slippa. W kontroli liczba żywych szpecieli była istotnie wyższa.

W doświadczeniu I, na plantacji w Kamionie, na krzewach chronionych preparatem Ortus 05 SC uszkodzonych przez szpeciela było 5,5-7,1\% pąków, zależnie od dawki, podczas gdy na krzewach niechronionych notowano ponad 36\% pąków uszkodzonych (tab. 1a). Po zabiegach preparatem Ortus 05 SC liczba uszkodzonych pąków była zredukowana o 80,6-85,0\% w stosunku do kontroli.

W doświadczeniu II, na krzewach chronionych preparatem Ortus 05 SC uszkodzonych było tylko 2,6-6,1\% pąków, a liczba ta była zredukowana o 76,8-90,1\% w stosunku do kontroli (ponad 26\% uszkodzonych pąków) (tab. 1b). Wyniki z preparatem Ortus 05 SC były podobne, jak ze standardem Marshal 250 SC. W obu doświadczeniach Ortus 05 SC i Ortus 05 SC + Slippa zastosowane 3 razy podczas migracji wielkopąkowca porzeczkowego, wykazały podobną efektywność (76,8-80,6\%).

W doświadczeniu III, preparat Ortus 05 SC zastosowany 1 raz na początku lub podczas pełni kwitnienia porzeczki czarnej, na pędach z zasiedlonymi pąkami przed zabiegiem, redukował liczbę pąków uszkodzonych o 36,6-41,4\% (tab. 2). Po dwóch zabiegach preparatem Ortus 05 SC i Ortus 05 SC + Slippa uzyskano wyższą efektywność, 67,6 i 46,1\% odpowiednio. Warto podkreślić, że na krzewach chronionych preparatem Ortus $05 \mathrm{SC}+$ Slippa, liczba zasiedlonych pąków wzrosła tylko o 19,9\%, a w kontroli aż o 85,0\% (tab. 2). Na pędach krzewów chronionych notowano od 8,3-16,3\% pąków zasiedlonych przez szpeciela, a w kontroli $-25,6 \%$, ale statystycznie nie było różnic. Analizując pędy oznaczone w 2009 roku przed zabiegami bez uszkodzeń przez wielkopąkowca, stwierdzono zdecydowanie mniej uszkodzeń, zarówno na krzewach chronionych $-1,5-2,7 \%$, jak i w kontroli $-4,2 \%$ (tab. 3). Efektywność po dwóch zabiegach preparatem Ortus 05 SC była wyższa $(59,5-64,1 \%)$, niż po jednym $(34,5-40,2 \%)$.

Tabela 1. Efektywność fenpiroksymatu (Ortus $05 \mathrm{SC}$ ) w zwalczaniu wielkopąkowca porzeczkowego (Cecidophyopsis ribis Westw.) na porzeczce czarnej odmiany Ben Lomond, Kamion 2008/2009 (a) i odmiany Ojebyn, Mokra Lewa 2008/2009 (b)

Table 1. Efficacy of fenpyroximate (Ortus 05 SC) in control of the blackcurrant gall mite (Cecidophyopsis ribis Westw.) on black currant cultivar Ben Lomond, Kamion 2008/2009 (a) and cultivar Ojebyn, Mokra Lewa 2008/2009 (b) a.

\begin{tabular}{|c|c|c|c|c|c|}
\hline \multirow{2}{*}{$\begin{array}{c}\text { Kombinacja* } \\
\text { Treatment }\end{array}$} & \multirow{2}{*}{$\begin{array}{c}\text { Dawka } \\
\text { Rate } \\
\text { [1/ha }]\end{array}$} & \multirow{2}{*}{$\begin{array}{c}\text { Liczba } \\
\text { zabiegów } \\
\text { No. of } \\
\text { treatments }\end{array}$} & \multicolumn{2}{|c|}{$\begin{array}{c}\text { Uszkodzone pąki - Damaged buds } \\
{[\%]}\end{array}$} & \multirow{2}{*}{$\begin{array}{c}\text { Efektywność } \\
\text { wg Abbotta } \\
\text { Efficacy acc. to } \\
\text { Abbott's formula } \\
\text { [\%] }\end{array}$} \\
\hline & & & $\begin{array}{c}\text { przed zabiegiem } \\
\text { before treatment } \\
1.04 .2008\end{array}$ & $\begin{array}{c}\text { po zabiegach } \\
\text { after treatments } \\
14.04 .2009\end{array}$ & \\
\hline Kontrola - Untreated & - & - & $11,6 \mathrm{a}$ & $36,6 \mathrm{~b}$ & - \\
\hline Ortus $05 \mathrm{SC}$ & 1,25 & 3 & $11,3 \mathrm{a}$ & $5,5 \mathrm{a}$ & 85,0 \\
\hline Ortus $05 \mathrm{SC}$ & 1,5 & 3 & $13,7 \mathrm{a}$ & $6,4 \mathrm{a}$ & 82,5 \\
\hline Ortus 05 SC + Slippa & $1,5+0,1$ & 3 & $12,1 \mathrm{a}$ & $7,1 \mathrm{a}$ & 80,6 \\
\hline Marshal 250 SC & 4,5 & 1 & $19,0 \mathrm{a}$ & $4,5 \mathrm{a}$ & 87,7 \\
\hline \multicolumn{6}{|l|}{ b. } \\
\hline Kontrola - Untreated & - & - & $12,8 \mathrm{a}$ & $26,3 \mathrm{~b}$ & - \\
\hline Ortus $05 \mathrm{SC}$ & 1,25 & 3 & $14,0 \mathrm{a}$ & $2,6 \mathrm{a}$ & 90,1 \\
\hline Ortus $05 \mathrm{SC}$ & 1,5 & 3 & $16,0 \mathrm{a}$ & $5,2 \mathrm{a}$ & 80,2 \\
\hline Ortus 05 SC + Slippa & $1,5+0,1$ & 3 & $13,9 \mathrm{a}$ & $6,1 \mathrm{a}$ & 76,8 \\
\hline Marshal 250 SC & 4,5 & 1 & $14,6 \mathrm{a}$ & $7,9 \mathrm{a}$ & 70,0 \\
\hline
\end{tabular}

Wartości średnie oznaczone w kolumnach tą samą literą nie różnią się istotnie przy p =0,05\%, test Newmana-Keulsa

Means followed by the same letter in each column are not significantly different (5\%) according to Newman-Keuls multiple range test

*3 zabiegi, początek migracji (przed pełnią kwitnienia), pełnia kwitnienia, koniec kwitnienia -3 treatments, before full of blossom, during full of blossom, at the end of blossom

1 zabieg po kwitnieniu (standard, zgodnie z rejestracją) - 1 treatment - just after blossom (standard, according to registration) 
Tabela 2. Efektywność fenpiroksymatu (Ortus 05 SC) w zwalczaniu wielkopąkowca porzeczkowego (Cecidophyopsis ribis Westw.) na porzeczce czarnej odmiany Ojebyn (na pędach z uszkodzonymi pąkami w 2009 roku), Mokra Lewa 2009/2010

Table 2. Efficacy of fenpyroximate (Ortus 05 SC) in control of the blackcurrant gall mite (Cecidophyopsis ribis Westw.) on black currant cultivar Ojebyn (on shoots with damaged buds in 2009), Mokra Lewa 2009/2010

\begin{tabular}{|c|c|c|c|c|c|}
\hline $\begin{array}{c}\text { Kombinacja* } \\
\text { Treatment }\end{array}$ & $\begin{array}{l}\text { Dawka } \\
\text { Rate } \\
{[1 / \text { ha }]}\end{array}$ & $\begin{array}{c}\text { Uszkodzone pąki } \\
\text { Damaged buds } \\
2009 \\
{[\%]}\end{array}$ & $\begin{array}{c}\text { Uszkodzone pąki } \\
\text { Damaged buds } \\
2010 \\
{[\%]}\end{array}$ & $\begin{array}{c}\text { Efektywność } \\
\text { wg Abbotta } \\
\text { Efficacy acc. to } \\
\text { Abbott's formula } \\
{[\%]}\end{array}$ & $\begin{array}{c}\text { Wzrost } \\
\text { uszkodzeń } \\
\text { Increase of } \\
\text { damaged buds } \\
2009 / 2010 \\
{[\%]}\end{array}$ \\
\hline Kontrola - Untreated & - & $13,9 \mathrm{a}$ & $25,6 \mathrm{a}$ & - & $+85,0$ \\
\hline $\begin{array}{l}\text { Ortus } 05 \mathrm{SC}-1 \mathrm{x} \text { początek } \\
\text { kwitnienia - beginning of blossom }\end{array}$ & 1,5 & $11,3 \mathrm{a}$ & $16,3 \mathrm{a}$ & 36,6 & $+43,3$ \\
\hline $\begin{array}{l}\text { Ortus } 05 \mathrm{SC}-1 \mathrm{x} \\
\text { pelnia kwitnienia - full of blossom }\end{array}$ & 1,5 & $8,5 \mathrm{a}$ & $15,0 \mathrm{a}$ & 41,4 & $+76,9$ \\
\hline $\begin{array}{l}\text { Ortus } 05 \mathrm{SC}-2 \mathrm{x} \\
\text { (1x początek }+1 \mathrm{x} \text { pełnia } \\
\text { kwitnienia })- \text { beginning and full } \\
\text { of blossom }\end{array}$ & 1,5 & $6,4 \mathrm{a}$ & $8,3 \mathrm{a}$ & 67,6 & $+30,7$ \\
\hline $\begin{array}{l}\text { Ortus } 05 \mathrm{SC}+\text { Slippa }-2 \mathrm{x}(1 \mathrm{x} \\
\text { początek }+1 \mathrm{x} \text { pełnia kwitnienia }) \\
\text { beginning and full of blossom }\end{array}$ & $1,5+0,1$ & $11,5 \mathrm{a}$ & $13,8 \mathrm{a}$ & 46,1 & $+19,9$ \\
\hline
\end{tabular}

Objaśnienia jak w tabeli 1. - For explanations see Table 1

*terminy opryskiwań: 24.04. i 5.05.2009, początek i pełnia kwitnienia - date of treatments: April 24 and May 5, 2009, before blossom and during full of blossom

Tabela 3. Efektywność fenpiroksymatu (Ortus 05 SC) w zwalczaniu wielkopąkowca porzeczkowego (Cecidophyopsis ribis Westw.) na porzeczce czarnej odmiany Ojebyn (na pędach bez uszkodzonych pąków w 2009 roku), Mokra Lewa 2009/2010

Table 3. Efficacy of fenpyroximate (Ortus 05 SC) in control of the blackcurrant gall mite (Cecidophyopsis ribis Westw.) on black currant cultivar Ojebyn (on shoots without damaged buds in 2009), Mokra Lewa 2009/2010

\begin{tabular}{l|c|c|c}
\hline \multicolumn{1}{c|}{$\begin{array}{c}\text { Kombinacja* } \\
\text { Treatment }\end{array}$} & $\begin{array}{c}\text { Dawka } \\
\text { Rate } \\
{[1 / h a]}\end{array}$ & $\begin{array}{c}\text { Uszkodzone pąki } \\
\text { Damaged buds } \\
2010 \\
{[\%]}\end{array}$ & $\begin{array}{c}\text { Efektywność wg Abbotta } \\
\text { Efficacy acc. to Abbott's } \\
\text { formula } \\
{[\%]}\end{array}$ \\
\hline Kontrola - Untreated & - & $4,2 \mathrm{a}$ & - \\
\hline Ortus 05 SC - 1x początek kwitnienia - beginning of blossom & 1,5 & $2,7 \mathrm{a}$ & 34,5 \\
\hline Ortus 05 SC - 1x pełnia kwitnienia - full of blossom & 1,5 & $2,6 \mathrm{a}$ & 40,2 \\
\hline $\begin{array}{l}\text { Ortus 05 SC - 2x (1x początek kwitnienia + 1x pełnia kwitnienia) - } \\
\text { beginning and full of blossom }\end{array}$ & 1,5 & $1,7 \mathrm{a}$ & 59,5 \\
\hline $\begin{array}{l}\text { Ortus 05 SC + Slippa - 2x (1x początek kwitnienia + 1x pełnia } \\
\text { kwitnienia) - beginning and full of blossom }\end{array}$ & $1,5+0,1$ & $1,5 \mathrm{a}$ & 64,1 \\
\hline
\end{tabular}

Objaśnienia jak w tabeli 1. - For explanations see Table 1

*terminy opryskiwań: 24.04. i 5.05.2009, początek i pełnia kwitnienia - date of treatments: April 24 and May 5, 2009, before blossom and during full of blossom

W doświadczeniu IV, Ortus 05 SC zastosowany 1 raz redukował uszkodzone pąki o 49,0-52,0\% na pędach $\mathrm{z}$ pąkami uszkodzonymi, natomiast o $55,0-74,0 \%$ na pędach bez uszkodzeń przed opryskiwaniem (tab. 4). Po dwóch zabiegach preparatem Ortus $05 \mathrm{SC}$ i Ortus $05 \mathrm{SC}+$ Slippa uzyskano wyższą efektywność, tj. 68,0 i 71,0\% lub 77,0 i $82,0 \%$ odpowiednio. Na pędach krzewów chronionych notowano od $1,8-3,1 \%$ lub $0,8-2,1 \%$ pąków zasiedlonych przez szpeciela, a w kontroli 6,2 lub 4,8\%. Na pędach z objawami uszkodzeń przed zabiegami, procentowo uszkodzeń było więcej. Nie było istotnych różnic między liczbą uszkodzonych pąków w zależności od liczby zabiegów, ale były istotne w porównaniu $\mathrm{z}$ kontrolą.
W doświadczeniu V, preparat Ortus 05 SC zastosowany 1 raz do zwalczania $C$. ribis na plantacji słabo zasiedlonej, redukował liczbę uszkodzonych pąków o $86,0-88,0 \%$ na pędach $\mathrm{z}$ pąkami uszkodzonymi, a o $63,0-66,0 \%$ na pędach bez uszkodzeń przed opryskiwaniem (tab. 5). Po dwóch opryskiwaniach preparatem Ortus 05 SC lub Ortus 05 SC + Slippa uzyskano efektywność 94,0 i 90,0\% lub 85,0 i 82,0\% odpowiednio, na pędach z lub bez uszkodzeń przed opryskiwaniem. Na pędach krzewów chronionych notowano $0,4-1,1 \%$ lub $0,5-$ 1,3\% pąków zasiedlonych przez szpeciela, podczas gdy na pędach krzewów kontrolnych 7,5 lub 3,5\%, jednak ten wyższy procent uszkodzeń notowano na pędach z uszko- 
Tabela 4. Efektywność fenpiroksymatu (Ortus 05 SC) w zwalczaniu wielkopąkowca porzeczkowego (Cecidophyopsis ribis Westw.) na porzeczce czarnej odmiany Ojebyn (na pędach z uszkodzonymi pąkami i bez uszkodzonych pąków w 2010 roku), Mokra Lewa 2010/2011

Table 4. Efficacy of fenpyroximate (Ortus 05 SC) in control of the blackcurrant gall mite (Cecidophyopsis ribis Westw.) on black currant cultivar Ojebyn (on shoots with damaged buds in 2010 and on shoots without damaged buds in 2010), Mokra Lewa 2010/2011

\begin{tabular}{|c|c|c|c|c|c|}
\hline \multirow[b]{2}{*}{$\begin{array}{l}\text { Kombinacja* } \\
\text { Treatment }\end{array}$} & \multirow[b]{2}{*}{$\begin{array}{l}\text { Dawka } \\
\text { Rate } \\
\text { [1/ha] }\end{array}$} & \multicolumn{2}{|c|}{$\begin{array}{l}\text { Na pędach bez uszkodzonych pąków } \\
\text { w } 2010 \text { roku } \\
\text { On shoots without damaged buds in } 2010\end{array}$} & \multicolumn{2}{|c|}{$\begin{array}{l}\text { Na pędach z uszkodzonymi pąkami } \\
\text { w } 2010 \text { roku } \\
\text { On shoots with damaged buds in } 2010\end{array}$} \\
\hline & & $\begin{array}{l}\text { uszkodzone pąki } \\
\text { damaged buds } \\
2011 \\
{[\%]}\end{array}$ & $\begin{array}{c}\text { efektywność } \\
\text { wg Abbotta } \\
\text { efficacy acc. to } \\
\text { Abbott's formula } \\
{[\%]}\end{array}$ & $\begin{array}{l}\text { uszkodzone pąki } \\
\text { damaged buds } \\
2011 \\
{[\%]}\end{array}$ & $\begin{array}{c}\text { efektywność } \\
\text { wg Abbotta } \\
\text { efficacy acc. to } \\
\text { Abbott's formula } \\
{[\%]}\end{array}$ \\
\hline Kontrola - Untreated & - & $4,8 \mathrm{~b}$ & - & $6,2 \mathrm{~b}$ & - \\
\hline $\begin{array}{l}\text { Ortus } 05 \mathrm{SC}-1 \mathrm{x} \text { początek } \\
\text { kwitnienia - beginning of blossom }\end{array}$ & 1,5 & $2,1 \mathrm{a}$ & 55,0 & $3,1 \mathrm{a}$ & 49,0 \\
\hline $\begin{array}{l}\text { Ortus } 05 \mathrm{SC}-1 \mathrm{x} \text { pełnia kwitnienia } \\
- \text { full of blossom }\end{array}$ & 1,5 & $1,2 \mathrm{a}$ & 74,0 & $2,9 \mathrm{a}$ & 52,0 \\
\hline $\begin{array}{l}\text { Ortus } 05 \mathrm{SC}-2 \mathrm{x}(1 \mathrm{x} \text { początek } \\
\text { kwitnienia }+1 \mathrm{x} \text { pełnia kwitnienia })- \\
\text { beginning and full of blossom }\end{array}$ & 1,5 & $1,1 \mathrm{a}$ & 77,0 & $1,9 \mathrm{a}$ & 68,0 \\
\hline $\begin{array}{l}\text { Ortus } 05 \mathrm{SC}+\text { Slippa }-2 \mathrm{x}(1 \mathrm{x} \\
\text { początek kwitnienia }+1 \mathrm{x} \text { pełnia } \\
\text { kwitnienia) }- \text { beginning and full of } \\
\text { blossom }\end{array}$ & $1,5+0,1$ & $0,8 \mathrm{a}$ & 82,0 & $1,8 \mathrm{a}$ & 71,0 \\
\hline
\end{tabular}

Objaśnienia jak w tabeli 1. - For explanations see Table 1

*terminy opryskiwań: 2010, początek i pełnia kwitnienia - date of treatments: 2010, before blossom and during full of blossom

Tabela 5. Efektywność fenpiroksymatu (Ortus 05 SC) w zwalczaniu wielkopąkowca porzeczkowego (Cecidophyopsis ribis Westw.) na porzeczce czarnej odmiany Tiben (na pędach z i bez uszkodzonych pąków w 2010 roku), Mokra Lewa 2010/2011

Table 5. Efficacy of fenpyroximate (Ortus 05 SC) in control of the blackcurrant gall mite (Cecidophyopsis ribis Westw.) on black currant cultivar Tiben (on shoots with damaged buds and on shoots without damaged buds in 2010), Mokra Lewa 2010/2011

\begin{tabular}{|c|c|c|c|c|c|}
\hline \multirow[b]{2}{*}{$\begin{array}{l}\text { Kombinacja* } \\
\text { Treatment }\end{array}$} & \multirow[b]{2}{*}{$\begin{array}{c}\text { Dawka } \\
\text { Rate } \\
\text { [1/ha] }\end{array}$} & \multicolumn{2}{|c|}{$\begin{array}{l}\text { Na pędach z uszkodzonymi pąkami } \\
\text { w } 2010 \text { roku } \\
\text { On shoots with damaged buds in } 2010\end{array}$} & \multicolumn{2}{|c|}{$\begin{array}{l}\text { Na pędach bez uszkodzonych pąków } \\
\text { w } 2010 \text { roku } \\
\text { On shoots without damaged buds in } 2010\end{array}$} \\
\hline & & $\begin{array}{l}\text { uszkodzone pąki } \\
\text { damaged buds } \\
2011 \\
{[\%]}\end{array}$ & $\begin{array}{c}\text { efektywność } \\
\text { wg Abbotta } \\
\text { efficacy acc. to } \\
\text { Abbott's formula } \\
\text { [\%] }\end{array}$ & $\begin{array}{c}\text { uszkodzone pąki } \\
\text { damaged buds } \\
2011 \\
{[\%]}\end{array}$ & $\begin{array}{c}\text { efektywność } \\
\text { wg Abbotta } \\
\text { efficacy acc. to } \\
\text { Abbott's formula } \\
\text { [\%] }\end{array}$ \\
\hline Kontrola-Untreated & - & $7,5 \mathrm{~b}$ & - & $3,5 \mathrm{~b}$ & - \\
\hline $\begin{array}{l}\text { Ortus } 05 \mathrm{SC}-1 \mathrm{x} \text { początek } \\
\text { kwitnienia - beginning of blossom }\end{array}$ & 1,5 & $1,1 \mathrm{a}$ & 86,0 & $1,2 \mathrm{a}$ & 66,0 \\
\hline $\begin{array}{l}\text { Ortus } 05 \mathrm{SC}-1 \mathrm{x} \text { pełnia kwitnienia } \\
- \text { full of blossom }\end{array}$ & 1,5 & $0,9 \mathrm{a}$ & 88,0 & $1,3 \mathrm{a}$ & 63,0 \\
\hline $\begin{array}{l}\text { Ortus } 05 \mathrm{SC}-2 \mathrm{x}(1 \mathrm{x} \text { początek } \\
\text { kwitnienia }+1 \mathrm{x} \text { pełnia kwitnienia }) \\
- \text { beginning and full of blossom }\end{array}$ & 1,5 & $0,4 \mathrm{a}$ & 94,0 & $0,5 \mathrm{a}$ & 85,0 \\
\hline $\begin{array}{l}\text { Ortus } 05 \mathrm{SC}+\text { Slippa }-2 \mathrm{x} \\
(1 \mathrm{x} \text { początek kwitnienia }+1 \mathrm{x} \\
\text { pełnia kwitnienia) }- \text { beginning and } \\
\text { full of blossom }\end{array}$ & $1,5+0,1$ & $0,7 \mathrm{a}$ & 90,0 & $0,6 \mathrm{a}$ & 82,0 \\
\hline
\end{tabular}

Objaśnienia jak w tabeli 1. - For explanation see Table 1

*terminy opryskiwań: 2010, początek i pełnia kwitnienia - date of treatments: 2010, before blossom and during full of blossom

dzonymi pąkami przed opryskiwaniem. Nie było różnic między wynikami na krzewach opryskiwanych 1 i 2 razy, ale różniły się istotnie od kontroli.
Preparat Ortus $05 \mathrm{SC}$ w dwóch testach laboratoryjnych i polowo-laboratoryjnych wykazał wysoką efektywność w redukcji szpecieli wychodzących z traktowanych pąków. 
Najwyższą efektywność uzyskano po zanurzaniu pąków w cieczy zawierającej Ortus $05 \mathrm{SC}+$ zwilżacz Slippa oraz stosując Ortus $05 \mathrm{SC}$ w wysokiej dawce $(2,0$ l/ha, w przeliczeniu). Wyniki te zostały potwierdzone wiosną 2009 roku (tab. 1a, b). We wszystkich badaniach polowych Ortus $05 \mathrm{SC}$ istotnie redukował wielkopąkowca porzeczkowego, ograniczając liczbę uszkodzonych przez niego pąków.

W pierwszych doświadczeniach preparat Ortus $05 \mathrm{SC}$ $(1,25 ; 1,51 /$ ha $)$ i Ortus $05 \mathrm{SC}(1,5 \mathrm{l} / \mathrm{ha})+$ Slippa $(0,1 \mathrm{l} / \mathrm{ha})$, w 7501 wody na ha, zastosowany 3 -krotnie podczas migracji wielkopąkowca porzeczkowego ograniczał liczbę uszkodzonych pąków o 76-90\% w porównaniu z kontrolą. Preparat Ortus $05 \mathrm{SC}(1,5 \mathrm{l} / \mathrm{ha})$ zastosowany dwukrotnie, na początku kwitnienia i podczas pełni kwitnienia porzeczki czarnej, istotnie redukował liczbę pąków zasiedlonych przez wielkopąkowca porzeczkowego. Na krzewach chronionych preparatem Ortus 05 SC $(1,5$ 1/ha) + Slippa $(0,1 \mathrm{l} / \mathrm{ha})$ notowano nieco mniej uszkodzonych pąków w porównaniu z zabiegami bez zwilżacza, ale różnice nie były istotne statystycznie.

Uzyskane wyniki wskazują, że preparat Ortus 05 SC może być zastosowany w programie zwalczania wielkopąkowca porzeczkowego. Ortus 05 SC użyty podczas kwitnienia zwalcza przędziorka chmielowca i ogranicza wielkopąkowca porzeczkowego (Łabanowska 2009).

Zwykle wyższą redukcję uszkodzeń powodowanych przez wielkopąkowca porzeczkowego notowano na pędach bez uszkodzonych pąków przed opryskiwaniem w porównaniu z pędami, na których przed pierwszym zabiegiem obecne były uszkodzone pąki.

Mimo pozytywnych wyników w hodowli odmian odpornych lub mało podatnych na zasiedlenie przez wielkopąkowca, także w Polsce (Gajek i wsp. 1996; Pluta i wsp. 2000; Rubauskis i wsp. 2006; Łabanowska i Pluta 2010) nadal niezbędne jest poszukiwanie środków do zwalczania tego szkodnika. Obiecujące wyniki w doświadczeniach uzyskano stosując spirotetramat (Movento $100 \mathrm{SC}$ ), ale dotychczas nie został on zarejestrowany do ochrony porzeczki (Łabanowska 2011; Łabanowska i Korzeniowski 2013). Fenpiroksymat (Ortus 05 SC) zwalcza także pokrewny gatunek, roztocza truskawkowca Phytonemus pallidus na truskawce (Labanowska 2006, 2014).

Przedstawione wyniki były wykorzystane w procesie rejestracji preparatu Ortus 05 SC do ochrony porzeczki czarnej przed wielkopąkowcem porzeczkowym.

\section{Wnioski / Conclusions}

1. Preparat Ortus $05 \mathrm{SC}(1,5 \mathrm{l} / \mathrm{ha}, \mathrm{w} 750 \mathrm{l}$ wody na ha), zastosowany na porzeczce czarnej dwa razy (na początku i w czasie pełni kwitnienia) lub trzykrotnie (na początku, podczas pełni i po kwitnieniu) istotnie redukował liczbę pąków zasiedlonych przez wielkopąkowca porzeczkowego (C. ribis).

2. Skuteczność preparatu Ortus $05 \mathrm{SC}(1,5 \mathrm{l} / \mathrm{ha}) \mathrm{z}$ dodatkiem zwilżacza Slippa $(0,1$ 1/ha) nie była istotnie wyższa niż po zastosowaniu środka bez zwilżacza.

3. Efektywność zwalczania wielkopąkowca porzeczkowego po 3 opryskiwaniach preparatem Ortus 05 SC była podobna, jak po jednym zabiegu preparatem standardowym Marshal 25 SC.

4. Uzyskane wyniki były podstawą rejestracji preparatu Ortus 05 SC do zwalczania C. ribis.

\section{Literatura / References}

Abbott M.S. 1925. A method of computing effectiveness of an insecticide. Journal of Economic Entomology 18: 265-267.

Alford D.V. 2007. Pests of Fruit Crops - A Colour Handbook. Imprint Academic Press, UK, 480 pp.

Brennan R., Jorgensen L., Gordon S., Loades K., Hacket Ch., Russell J. 2009. The development of a PCR-based marker linked to resistance to the blackcurrant gall mite (Cecidophyopsis ribis Acari: Eriophyidae). Theoretical and Applied Genetics 118: $205-211$.

Brennan R., Lanham P., McNicol R. 1993. Ribes breeding and research in the UK. Proceedings 6th International Symposium Rubus and Ribes. Skierniewice, July 3-10, 1993. Acta Horticulturae 352: 267-281.

Brennan R., Stewart D., Russell J. 2008. Developments and progress in Ribes breeding. Acta Horticulturae 777: 49-56.

Gajek D. 2000. The natural enemies of the blackcurrant gall mite (Cecidophyopsis ribis Westw.). Materiały XXVI Symposium Acarologicznego „Akarologia polska u progu nowego tysiąclecia”. Kazimierz Dolny, 24-26.10.1999: 285-288.

Gajek D., Nowacki J., Boczek J. 1996. Black currant cultivars resistant to the gall mite (Cecidophyopsis ribis Wesw.) as an element of integrated pest management. IOBC/WPRS Bulletin 19 (4): 349-350.

Gajek D., Olszak R.W. 2004. Wielkopąkowiec porzeczkowy (Cecidophyopsis ribis /Westw./) aktualne możliwości jego zwalczania. Ogólnopolska Naukowa Konferencja Ochrony Roślin Sadowniczych. Instytut Sadownictwa i Kwiaciarstwa, Skierniewice, 25-26.02.2004: 87-88.

Jones A.T. 1993. Possibilities and problems for the control of viruses infecting Rubus and Ribes crops in Europe. Proceedings 6th International Symposium Rubus and Ribes. Skierniewice, July 3-10, 1993. Acta Horticulturae 352: 547-553.

Łabanowska B.H. 1996. Biologiczne podstawy kompleksowej ochrony porzeczki czarnej przed najważniejszymi szkodnikami. Zeszyty Naukowe Instytutu Sadownictwa i Kwiaciarstwa, Monografie i rozprawy, 110 ss.

Labanowska B.H. 2006. Pottential agents for controlling the strawberry mite (Phytonemus palidus ssp. fragariae Zimm.) after the withrawal of endosulfan. Journal of Fruit and Ornamental Plant Research 14 (Suppl. 3): 67-72.

Łabanowska B.H. 2009. Nowe problemy w ochronie jagodników przed szkodnikami powodowane wycofaniem kilku substancji aktywnych zawartych w stosowanych środkach ochrony roślin. 52. Ogólnopolska Konferencja Ochrony Roślin Sadowniczych. Centrum Kongresowe, Ossa, 18-19.03.2009: 128-134.

Łabanowska B.H. 2010. Komentarz do programu ochrony porzeczki i agrestu oraz aronii przed szkodnikami. Ogólnopolska Konferencja Nauka Praktyce „Intensyfikacja uprawy roślin jagodowych przez wdrażanie najnowszych wyników badań” Uprawa porzeczek i agrestu. Skierniewice, 20.04.2010: 55-60. 
Łabanowska B.H. 2011.The big bud mite Cecidophyopsis ribis (Westw.) as a pest of blackcurrant and the possibility of its control in Poland. IOBC/WPRS Bulletin 70: 87-92.

Łabanowska B.H., Gajek D. 2013. Szkodniki krzewów owocowych. Plantpress, Kraków, 200 ss.

Łabanowska B.H. 2014. Ocena biologicznej skuteczności preparatu Ortus 05 SC (fenpiroksymat) w zwalczaniu roztocza truskawkowca (Phytonemus pallidus Banks) na truskawce po zbiorze owoców. [Efficacy of Ortus 05 SC (fenpiroxymate) in the control of the strawberry mite (Phytonemus pallidus Banks) on strawberry plantations after fruit harvest]. Progress in Plant Protection 54 (1): 44-50.

Łabanowska B.H., Korzeniowski M. 2013. The possibility to control the big bud mite (Cecidophyopsis ribis Westw.) on blackcurrant in Poland with a new active ingredient spirotetramat (Movento 100 SC). Proceedings of the 8th International Conference on Integrated Fruit Production. Turkey, Kusadasi, October 7-12, 2012. IOBC/WPRS Bulletin 91: 281-286.

Łabanowska B.H., Pluta S. 2010. Assessment of big bud mite (Cecidophyopsis ribis Westw.) infestation level of blackcurrant genotypes in the field. Journal of Fruit and Ornamental Plant Research 18 (2): 283-295.

Niemczyk E., Łabanowska B.H., Gajek D. 2000. Preliminary IPM program for blackcurrant crop for Poland. IOBC/WPRS Bulletin 23 (7): 141-144.

Pluta S., Żurawicz E. 2002. Effect of reversion virus on the yield and fruit size in blackcurrant Ribes nigrum L. Proceedings 8th International Symposium Rubus and Ribes. Scotland, Dundee. July 2001. Acta Horticulturae 585 (1): 393-398.

Pluta S., Żurawicz E., Malinowski T., Gajek D. 2000. Breeding of blackcurrant (Ribes nigrum L.) resistant to gall mite and reversion virus. Eucarpia symposium on fruit breeding and genetics. Acta Horticulturae 538: 463-468.

Rubauskis E., Strautina S., Surikova V. 2006. Importance of cultivar choice in preventing infestation by the blackcurrant gall mite (Cecidophyopsis ribis Westw.) on black currant plantations. Journal of Fruit and Ornamental Plant Research 14 (Suppl. 3): $209-215$.

Salamon Z. 1993. Mechanical harvest of black currants and their sensitivity to damage. Proceedings 6th International Symposium Rubus and Ribes. Skierniewice, July 3-10, 1993. Acta Horticulturae 352: 109-112.

Smolarz S. 1993. New insecticides in the control of big bud mite (Cecidophyopsis ribis Westw.) on black currant. Proceedings 6th International Symposium Rubus and Ribes. Skierniewice, July 3-10, 1993. Acta Horticulturae 352: 597-600. 